\title{
PEMBINAAN AKHLAK SISWA SMP/SL (SEKOLAH LINGKUNGAN) DI SEKOLAH ALAM DAGO, BANDUNG
}

\author{
Agis Aji Pratiwi, ${ }^{*}$ \\ Munawar Rahmat, Agus Fakhruddin \\ Program Studi Ilmu Pendidikan Agama Islam, \\ Fakultas Pendidikan Ilmu Pengetahuan Sosial, Universitas Pendidikan Indonesia \\ Email: agis.aji.pratiwi@gmail.com
}

\begin{abstract}
ABSTRAK
Sekolah merupakan tempat untuk menimba ilmu dan mencetak para generasi bangsa. Banyak hal yang didapatkan dari sekolah melalui program-program atau kegiatan yang ada di sekolah tersebut, namun program atau kegiatan itu sebagian besar hanya mengacu pada pembelajaran kognitif, sehingga sikap atau norma siswa menjadi kurang terbina dengan baik. Tujuan dari penelitian ini adalah 1) mengetahui perencanaan pembinaan akhlak siswa SL di sekolah alam Dago, Bandung; 2) Mengetahui substansi materi pembinaan akhlak siswa SL di sekolah alam Dago, Bandung; 3) Mengetahui pelaksanaan pembinaan akhlak siswa SL di sekolah alam Dago, Bandung; 4) Mengetahui hasil pembinaan akhlak siswa SL di sekolah alam Dago, Bandung. Metode yang digunakan dalam penelitian ini adalah metode deskriptif dengan pendekatan yang digunakan adalah pendekatan kualitatif. Data yang diolah berasal dari data wawancara, observasi dan dokumentasi. Perencanaan penelitian ini dibuat oleh kepala sekolah dengan tambahan saran dari guru dan orangtua siswa yang dilakukan diawal dan akhir semester, sumber penentuan point akhlak diadopsi dari al-Qur'an, hadits dan care value (nilai inti). Substansi atau inti dari materi akhlak didapatkan dari berbagai sumber buku, namun tetap mengacu pada buku kurikulum 2013. Pelaksanaan penelitian dilakukan setiap hari dengan program kegiatan yang telah disepakati, pihak yang terlibat dalam pelaksanaan mencakup semua anggota sekolah termasuk kepala sekolah yang juga selain ikut berpartisipasi dalam pelaksanaan juga berwenang untuk mengawasi jalannya kegiatan. Hasil penelitian atau evaluasi kegiatan pembinaan berupa dua macam raport, yakni: raport nilai dan groovy yang berisi perkembangan sikap dan keterampilan siswa.
\end{abstract}

Kata Kunci: Pembinaan Akhlak; Sekolah Alam, SL (Sekolah Lingkungan). 


\section{PENDAHULUAN}

\begin{abstract}
Sekolahmerupakansuatuwadah yang didalamnyaterjadi proses belajarmengajarantarasiswadan guru. Sekolah tidak hanya berlangsung didalam gedung sekolah, namun juga dapat berlangsung di alam terbuka seperti sekolah alam. Sekolah Alam merupakan salah satu jenis sekolah yang sama halnya dengan sekolah pada umumnya, ada siswa dan ada guru, hanya saja keterbatasan wadah/ tempat membuat proses belajar mengajar menjadi sedikit berbeda. Jika sekolah pada umumnya menggunakan ruang kelas dan media yang tersedia dengan apiknya diruangan, maka pada sekolah alam, ruangan dibuat menyatu dengan alam, mediapun semuanya berasal dari alam.
\end{abstract}

Arus globalisasi semakin deras kearah yang negatif. Arus negatif membuat siswa menjadi sulit terkendali, banyak perilaku siswa yang keluar dari norma agama, contohnya: membolos sekolah, berani membantah guru, terjadinya tawuran antarsesama pelajar, dll. Perilaku menyimpang tersebut disebabkan kurang terbinanya akhlak siswa.

\section{Al-Zuhailimelakukan}

penelitian mengenai penyimpangan sikap yang dilakukan siswa kedalam enam bagian. Pertama, penyimpangan moral, disebabkan meninggalkan perilaku baik dan mulia, lalu menggantinya dengan perbuatan buruk, seperti, bolos sekolah, suka berbohong. Kedua, penyimpangan berpikir, disebabkan adanya kekosongan pikiran, kekeringan rohani dan kedangkalan keyakinan, seperti, fanatik terhadap sesuatu, terbuai dalam khayalan.
Ketiga, penyimpangan agama, disebabkan sikap ekstrem dalam memahami ajaran agama, sehingga munculnya sikap fanatik terhadap suatu mazhab atau kelompoknya, seperti, skeptis terhadap keyakinan sendiri, memperjualbelikan agama. Keempat, penyimpangan sosial dan hukum, disebabkan sikap yang selalu melakukan kekerasan, seperti, mengancam, merampas, membunuh. Kelima, penyimpangan mental, disebabkan sikap yang selalu merasa tersisih, memiliki kepribadian ganda, cepat berputus asa, bimbang dan sering bingung. Keenam, penyimpangan ekonomi, disebabkan sikap congkak dan gengsi dengan kekayaan yang dimiliki, boros, berfoya-foya, membuang waktu untuk hal yang tidak penting (Zahruddin \& Sinaga, 2004, hal. 83-85).

Oleh karena itu, dalam bukunya Syafaat (2008, hal. 34) menyatakan bahwa yang seharusnya diajarkan para guru untuk menumbuhkan pola kepribadian siswa yang positif adalah dengan melatih kejiwaan, kecerdasan otak, penalaran, perasaan dan indera guna meningkatkan spiritual, intelektual, imajinasi, jasmaniah, ilmiah maupun bahasa, sehingga menjadikan siswa tersebut berkualitas.

Meskipun para siswa telah mempelajari dan mengetahui hal-hal yang benar dan yang salah, sebagaimana yang telah diajarkan oleh guru mereka, masih ada saja siswa yang pura-pura tidak tahu bahkan dengan sengaja melanggar normanorma, sehingga moral mereka menjadi semakin rendah. Hal-hal yang 
membuat norma dan moral siswa menjadi rendah, seperti: bolos sekolah, mencuri, minum-minuman keras, narkoba, bahkan membunuh. Hal negatif tersebut tidak serta merta datang dari dalam diri siswa. Banyak faktor yang mendorong siswa untuk terus saja melakukan hal-hal yang negatif tersebut, yakni: keluarga yang brokenhome, lingkungan sekolah yang kurang bersahabat, lingkungan masyarakat yang tidak kondusif, serta pergaulan bebas yang sulit terkontrol. Dari situlah siswa sangat mudah terpengaruh melakukan hal-hal yang negatif.

Berdasarkan permasalahan diatas, peneliti merasa tertarik untuk membahas dan meneliti lebih jauh mengenai upaya membina akhlak siswa agar menjadi lebih baik dan tetap istiqāmaћ sehingga menjadi pribadi yang senantiasa taat (menjalani perintah-Nya dan menjauhi laranganNya) pada Allāh SWT, maka peneliti akan melakukan penelitian yang berjudul: "Pembinaan Akhlak Siswa SMP/ SL (Sekolah Lingkungan) di Sekolah Alam Dago, Bandung."

Pendidikan agama Islām adalah bimbingan yang diberikan seseorang kepada seseorang agar ia berkembang secara maksimal sesuai dengan ajaran Islām (Tafsir, 2011, hal. 26).

Dalam Kamus Besar Bahasa Indonesia Edisi Keempat, pengertian pembinaan adalah usaha, tindakan dan kegiatan yang dilakukan secara efisien dan efektif untuk memperoleh hasil yang lebih baik (Balai Pustaka, 2008, hal. 193).

Menurut Sudjana (2010, hal. 200) pembinaan meliputi dua subfungsi yaitu pengawasan (controlling) dan supervisi (supervising). Pengawasan dilakukan baik terhadap kegiatan yang sedang dilaksanakan oleh organisasi maupun terhadap komponen-komponen organisasi. Supervisi merupakan upaya untuk membantu pembinaan dan peningkatan kemampuan pihak yang disupervisi agar mereka dapat melaksanakan tugas kegiatan yang telah ditetapkan secara efisien dan efektif.

Menurut pendekatan etimologi, akhlak berasal dari bahasa Arab jama' dari bentuk mufradnya "khuluqun (خلق)" yang menurut logat diartikan: budi pekerti, perangai, tingkah laku atau tabiat. Sedang dalam bahasa Inggrisnya disamakan dengan istilah moral atau ethic. Begitupun dalam bahasa Yunani istilah akhlak dipergunakan istilah ethos atau ethikos atau etika (Zahruddin \& Sinaga, 2004, hal. 1-2).

Iman Abdul Mukmin

Sa'aduddin (2006, hal. 61-92), membagi metode akhlak kedalam lima langkah, yakni: memberi pelajaran atau nasihat, membiasakan akhlak yang baik, memilih teman yang baik, memberi pahala dan sanksi serta memberi keteladanan yang baik.

Anshori (Susapti, hal. 2), sekolah alam sebagai sebuah sekolah atau lembaga yang dijadikan alternatif bagi siswa yang menginginkan suasana berbeda dalam pembelajaran. Sekolah alam identik dengan suasana hijau yang didapat dari pepohonan serta rerumputan yang ada disekitarnya. Dengan begitu, siswa tidak hanya belajar mengenai teori saja, tetapi juga praktek langsung. Selain itu juga, dengan adanya komunikasi antara manusia dan alam, membuat manusia tidak hanya dapat memanfaatkan alam saja, tetapi juga harus mampu merawat alam dengan sebaik-baiknya.

Manajemen berasal dari bahasa latin, yaitu manus yang berarti tangan 
dan agere yang berarti melakukan. Kedua kata tersebut digabung menjadi kata kerja managre yang artinya menangani. Managere diterjemahkan kedalam bahasa Inggris management dan manager untuk orang yang melakukan kegiatan manajemen. Kata management diterjemahkan ke dalam bahasa Indonesia menjadi manajemen dan pengelolaan (Usman, 2010, hal. 4).

Dalam pelaksanaannya, terdapat empat fungsi manajemen yang menunjang terlaksananya proses manajemen. keempat fungsi tersebut yakni: perencanaan, pengorganisasian, pengendalian dan motivasi (Siswanto, 2010, hal. 42).

\section{METODE}

Nasution (1987, hal. 40-41), mendefinisikan desain penelitian sebagai rencana tentang cara mengumpulkan dan menganalisis data agar dapat dilaksanakan secara ekonomis serta serasi dengan tujuan penelitian. Desain penelitian berguna dalam tiga hal, yakni: memberi pegangan mengenai segala sesuatu yang harus dipikirkan, menentukan batas-batas penelitian dan mengaitkannya dengan tujuan yang jelas agar tersusun dan terdesain serta memberi gambaran agar dapat mengetahui macam-macam kesulitan yang akan dihadapi peneliti.

Dalam penelitian ini, desain yang digunakan adalah case study atau studi kasus, dimana penelitian hanya berpusat mengenai pembinaan akhlak yang diterapkan pada sekolah alam Dago, Bandung. Untuk mengunakan desain ini, pengumpulan data diperoleh dari proses observasi, wawancara dan dokumentasi. Dari proses tersebut, bahan yang didapatkan berupa laporan hasil pengamatan yang dilakukan selama observasi, data mengenai perencanaan, pelaksanaan dan evaluasi yang didapatkan dari hasil wawancara serta catatan pribadi peneliti yang berisi proses pembinaan akhlak yang didapatkan dari hasil dokumentasi pribadi maupun dari sekolah.

Dimana menurut Nasution (1987, hal. 27) Case study (studi kasus) adalah bentuk penelitian yang mendalam tentang suatu aspek lingkungan sosial termasuk manusia didalamnya.

Partisipan sangat membantu peneliti dalam penyelesaian skripsi ini. Orang yang berperan sebagai subjek dari penelitian ini adalah mereka yang turut serta dalam pelaksanaan pembinaan akhlak, yakni: kepala sekolah yang memberikan arahan dan pengawasan, guru-guru SL yang membimbing dan mengawasi siswa serta semua siswa SL yang melaksanakan kegiatan pembinaan.

Pendekatan yang peneliti gunakan adalah pendekatan kualitatif dengan metode deskriptif, Penelitian deskriptif pada umumnya dilakukan dengan tujuan utama, yaitu menggambarkan secara sistematis fakta dan karakteristik objek dan subjek yang diteliti secara tepat. Metode penelitian deskriptif banyak dilakukan oleh para peneliti karena dua alasan. Pertama, dari pengamatan empiris didapat bahwa sebagian besar laporan penelitian dilakukan dalam bentuk deskriptif. Kedua, metode deskriptif sangat berguna untuk mendapatkan variasi permasalahan yang berkaitan dengan bidang 
pendidikan maupun tingkah laku manusia (Sukardi, 2013, hal. 157).

Sebagaimana yang di jelaskan Sukmadinata (2011, hal. 54), bahwa ada beberapa metode penelitian yang terdapat pada penelitian kualitatif yang bersifat noneksperimental, yaitu: metode deskriptif, survei, ekspos fakto, komparatif, korelasional dan penelitian tindakan. Dalam hal ini, penelitian deskriptif adalah suatu metode penelitian yang ditujukan untuk menggambarkan fenomena-fenomena yang ada, yang berlangsung pada saat ini atau saat yang lampau.

Penelitian deskriptif pada umumnya dilakukan dengan tujuan utama, yaitu menggambarkan secara sistematis fakta dan karakteristik objek dan subjek yang diteliti secara tepat. Metode penelitian deskriptif banyak dilakukan oleh para peneliti karena dua alasan. Pertama, dari pengamatan empiris didapat bahwa sebagian besar laporan penelitian dilakukan dalam bentuk deskriptif. Kedua, metode deskriptif sangat berguna untuk mendapatkan variasi permasalahan yang berkaitan dengan bidang pendidikan maupun tingkah laku manusia (Sukardi, 2013, hal. 157).

Teknik pengumpulan data merupakan langkah yang paling strategis dalam penelitian, karena tujuan utama dari penelitian adalah mendapatkan data. Tanpa mengetahui teknik pengumpulan data, maka peneliti tidak akan mendapatkan data yang memenuhi standar data yang diterapkan (Sugiyono, 2008, hal. 62).

Bermacam-macam teknik yang digunakan dalam pengumpulan data, peneliti mengambil tiga jenis diantaranya, yakni teknik observasi, wawancara dan dokumentasi.
Observasi dilakukan untuk memperoleh informasi tentang kelakuan manusia seperti terjadi dalam kenyataan. Dengan observasi dapat diperoleh gambaran yang lebih jelas tentang kehidupan sosial, yang sulit diperoleh dengan metode lain (Nasution, 1987, hal. 141).

Wawancara atau interview adalah suatu bentuk komunikasi verbal yakni semacam percapakan yang bertujuan memperoleh informasi. Interview dilakukan antara dua orang tetapi dapat juga sekaligus diinterview dua orang atau lebih.

Studi dokumentasi yaitu mengumpulkan dokumen dan datadata yang diperlukan dalam permasalahan penelitian lalu ditelaah secara detail sehingga dapat mendukung dan menambah kepercayaan dan pembuktian suatu kejadian.

\section{HASIL DAN PEMBAHASAN}

\section{Profil}

Sekolah alam Dago, Bandung memiliki visi dan misi. Visi sekolah alam Dago, Bandung yakni menjadilembagapendidikan yang mengarahdanberbasiskepadaAl-

Qur'āndanSunnah, back to naturedansustainable development. Adapun visi diatas diturunkan menjadi misi-misi berikut dengan mengembangkan aspek sumber daya manusia: (a) Al-Akhlaqūl Karīmah (sikap hidup), menuntun anak didik pada perilaku yang sesuai dengan alqurān dan sunnah Rasūlullāh SAW, (c) falsafah Ilmu Pengetahuan dan Sikap Ilmiah yang berdasarkan integrasi iman dan ilmu, dan (c) kepemimpinan (leadership), kemampuan mengelola 
kehidupan secara harmonis dan bijaksana (Dk 2).

Kurikulum yang digunakan sekolah alam Dago, Bandung menekankan proses pembelajaran yang disampaikansecaraactivedanfun, karenasecaralahiriahanaklebihsukabera dadalamruangan yang informal, terbukadanbebasdibandingkandengans uasana yang formal, tertutupdenganlingkungan yang terbatas.

Program pembinaan akhlak yang diterapkan sekolah alam Dago, Bandung ada lima kegiatan, yakni: kegiatan ibadah, mata pelajaran PAI, proses pembelajaran, tausiah dan kegiatan mabit. Kelima kegiatan tersebut dijalankan sebagaimana mestinya dengan langkah pembinaan akhlak berikut:

\section{Perencanaan}

Sekolah alam juga melakukan perencanaan dalam menyusun program kegiatan, agar dalam pelaksanaan nantinya berjalan dengan baik dan memperoleh hasil yang diinginkan. Banyak hal yang diperhitungkan dalam sebuah perencanaan, seperti: orang yang merencanakan, objek yang direncanakan, serta sarana dan prasarana untuk menjalankan kegiatan. Subjek yang merencanakan dalam hal pembinaan akhlak ini adalah kepala sekolah, guru dan orangtua siswa. Objek yang direncanakan adalah siswa yang menjalankan kegiatan tersebut. Sedangkan sarana dan prasarana yang menjadi media pelaksanaan adalah ruang kelas, aula dan lapangan sekolah. Setelah ketiga hal tersebut diperhitungkan, maka langkah selanjutnya adalah mencari masalah dan informasi-informasi dari masalah tersebut, merumuskannya dan mencari jalan keluar dari permasalahan tersebut. Dari pertimbangan masalah tersebut, maka akan menghasilkan program kegiatan dengan yang diterapkan kedalam beberapa program yang telah direncanakan, antara lain: Kegiatan ibādaћ, Membaca al-qurān, Hapalan surah-surah, Tausiāh bergilir, Malam Bina Iman dan Takwa (MABIT), serta dalam kegiatan belajar mengajar di kelas.

Sejalan dengan pendapat (Purwanto, 2012, hal. 42), dalam memperhitungkan suatu perencanaan, juga harus mengikuti proses atau langkah-langkah dalam perumusan tersebut, yakni: menentukan dan merumuskan tujuan yang hendak dicapai, meneliti masalah-masalah atau pekerjaan-pekerjaan yang akan dilakukan, mengumpulkan data dan informasi-informasi yang diperlukan, menentukan tahap-tahap atau rangkaian tindakan dan merumuskan bagaimana masalah-masalah itu akan dipecahkan dan bagaimana pekerjaanpekerjaan itu akan diselesaikan.

\section{Substansi}

Materi akhlak di sekolah alam Bandung merupakan campuran dari rancangan pemerintah dan rancangan sekolah alam. Kelas 1, materi akhlak yang dipelajari: Hidup jadi lebih damai dengan ikhlās, sabar dan pemaaf; Berprilaku amanah dan istiqāmaћ; Berbusana yang baik dan sopan menurut Islām Kelas 2 dan 3, materi akhlak yang dipelajari, yakni: Akhlak qanā'ah, Tasamuh dan Memahami kandungan surah Luqman: 18 tentang jangan memalingkan muka dan sombong (WWl 1, Dk 4, Dk 5). 
Substansi dari materi-materi akhlak tersebut adalah pengamalan. Maksudnya, materi dapat dikuasai siswa jika materi tersebut dapat diamalkan siswa secara teori dan praktek. Teori dikuasai jika siswa mendapatkan nilai dari materi yang dihapal. Sedangkan praktek, selain siswa mengetahui, siswa juga mampu mengamalkannya di kehidupan seharihari. Sehingga selain nilai yang berpengaruh, sikap dan keterampilan juga menjadi penentu pemahaman siswa terhadap materi tersebut (WWl $1)$.

Pengamalan tersebut sesuai dengan pengertian akhlak yakni ilmu yang membahas tentang perbuatan mulia serta cara mengupayakan perbuatan tersebut dan tentang perbuatan buruk serta cara menjauhkannya (Sa'aduddin, 2006, hal. 18).

\section{Pelaksanaan}

Pelaksanaan pembinaan akhlak yang di programkan sekolah alam Bandung adalah kegiatan ibādah, membaca al-qurān, hapalan suraћsurah, tausiah bergilir, malam bina iman dan takwa (MABIT), serta pembinaan yang dilakukan dalam kegiatan belajar mengajar dikelas, seperti pada ppelajaran agama Islām dan pelajaran lainnya. Pihak-pihak yang merealisasikannya adalah kepala sekolah, wali kelas SL, guru-guru yang mengajar di SL, mereka berupaya memberi teladan yang baik kepada siswa dengan melakukan segala sesuatu sesuai syarī'a $\hbar$ dan juga sesuai dengan pembinaan akhlak yang telah ditetapkan dirapat kerja. Sedangkan siswa sebagai subjek utama dalam pembinaan akhlak ini tentunya berupaya untuk menjalankan pembinaan akhlak sebaikbaiknya (WKp).

Menurut Ernest Dale (Fattah, 2011, hal. 72) dalam melakukan suatu pembinaan, terhadap beberapa langkah agar kegiatan terorganisir dengan baik, yang biasanya dilakukan dari atasan kepada bawahan. Tahap pertama, merinci pekerjaan yakni menentukan tugas-tugas apa yang harus dilakukan untuk mencapai tujuan organisasi. Tahap kedua, membagi seluruh beban kerja menjadi kegiatan-kegiatan yang dapat dilaksanakan oleh perseorangan atau perkelompok. Tahap ketiga, menggabungkan pekerjaan para anggota dengan cara yang rasional, efisien. Tahap keempat, menetapkan mekanisme kerja untuk mengkoordinasikan pekerjaan dalam satu kesatuan yang harmonis. Tahap kelima, melakukan monitoring dan mengambil langkah-langkah penyesuaian untuk mempertahankan dan meningkatkan efektivitas.

Prosedur pembinaan yang dilaksanakan secara menyeluruh, digambarkan Sudjana (2010: 224) melalui lima langkah pokok yang berurutan, yakni: mengumpulkan informasi, mengidentifikasi masalah, menganalisis masalah, mencari dan menetapkan serta melaksanakan upaya pemecahan masalah.

Sejalan dengan Sudjana, sekolah alam juga melaksanakan program kegiatan pembinaan akhlak menggunakan prosedur guna mendapatkan hasil yang maksimal. Pertama, mengumpulkan informasi yang didapatkan dari orangtua siswa, guru dan teman mengenai perilaku siswa di rumah dan sekolah. Kedua, mengidentifikasi masalah dengan 
memilih masalah yang dianggap perlu untuk dibina. Ketiga, menganalisis masalah dengan membahas masalah tersebut. Keempat, mencari dan menetapkan yakni mencari jalan keluar dan menetapkan apa yang harus diperbuat dalam menanggulangi masalah tersebut. Kelima, upaya pemecahan masalah yakni dengan melakukan pembinaan dan mempraktekkannya (WKp).

Masing-masing siswa memiliki sikap/ akhlak yang berbeda-beda. Sepanjang penelitian berlangsung, baik pengamatan melalui observasi maupun secara langsung dengan wawancara ke sejumlah siswa, peneliti menyimpulkan bahwa sikap mereka dipengaruhi oleh 2 dari keempat hal diatas, yakni: adat/ kebiasaan dan milieu. Adat/ kebiasaan, terlihat dari apa yang mereka lakukan selama kegiatan pembelajaran berlangsung dan juga didapatkan dari teman-teman sekelasnya. Milieu terlihat dari pergaulan siswa saat jam istirahat dan saat pelajaaran yang berhubungan dengan alam.

Setelah melihat proses pembinaan akhlak yang dilakukan sekolah alam Bandung, maka seyogyanya metode yang digunakan mencakup lima hal, sebagaimana yang dikemukakan Iman Abdul Mukmin Sa'aduddin (2006, hal. 61-92), yakni: memberi pelajaran atau nasihat, membiasakan akhlak yang baik, memilih teman yang baik, memberi pahala dan sanksi serta memberi keteladanan yang baik.

Kelima metode diatas diterapkan dalam sekolah alam. Pertama, memberi pelajaran atau nasihat yang dilakukan guru setiap harinya, baik dalam kegiatan pembelajaran maupun diluar kegiatan pembelajaran, metode ini dilakukan guru dengan cara, memberi pelajaran mengenai materi mata pelajaran yang dibarengi dengan menerapkan pembinaan akhlak secara teori dan praktek, serta memberi nasihat agar pembinaan akhlak tersebut dipraktekkan dikehidupan sehari-hari.

Kedua, membiasakan akhlak yang baik, contohnya: membiasakan untuk selalu mengucapkan salam saat hendak masuk dan keluar ruangan serta saat bertemu sesama muslim dan membiasakan untuk saling mambantu teman saat dalam suka maupun duka.

Ketiga, memilih teman yang baik. Oleh karena itu, dengan adanya metode ini, hendaknya siswa mampu memilih teman yang baik, mampu mengajak ke jalan yang benar, mampu membantu saat sedang kesulitan membuat pekerjaan rumah, dan sebagainya.

Keempat, memberi pahala dan sanksi. Pahala diibaratkan hadiah yang diberikan saat siswa menunjukkan prestasi, sedangkan sanksi diibaratkan hukuman yang diberikan saat siswa melakukan kesalahan. Pahala/ hadiah yang biasanya diberikan kepada siswa berupa nilai, kado khusus atau pujian. Sedangkan sanksi/ hukuman yang biasanya diberikan kepada siswa berupa sanksi yang telah ditetapkan sekolah ataupun berdasarkan kesepakatan bersama.

Kelima, memberi keteladanan yang baik. Keteladanan bagi siswa dalam sekolah adalah guru dan juga teman. Guru dijadikan teladan karena guru senantiasa memberikan pengajaran yang bersifat mendidik, sedangkan siswa memberi teladan kepada siswa lainnya karena adanya 
nilai lebih yang baik yang bisa dijadikan contoh. Teladan yang baik menurut Islām sebagaimana teladan yang dilakukan Rasūlullāh SAW.

5. Evaluasi

Penilaian yang digunakan sekolah alam Bandung untuk mengukur keberhasilan pembinaan akhlak yang diterapkan siswa adalah penilaian secara tertulis dalam bentuk raport dan juga penilaian secara groovy dalam bentuk kata-kata. Dalam raport yang tertera adalah nilai-nilai dari mata pelajaran umum, sedangkan dalam groovy yang tertera adalah tanda senyum pada kolom belum tampak (bagi siswa belum mampu memahami dan mempraktekkan) berkembang (bagi siswa baru mampu memahami namun belum bisa mempraktekkan) dan mandiri (bagi siswa yang sudah mampu memahami dan mempraktekkan) (WWl 1, WWl $3)$.

Arifin (2009: 124) mengemukakan terdapat beberapa sistem dalam melakukan evaluasi pembelajaran. Jika dilihat dari bentuk jawaban peserta didik, maka tes atau evaluasi dapat dibagi menjadi tiga jenis, yakni: tes lisan, tes tertulis dan tes perbuatan.

\section{KESIMPULAN}

Pembinaan akhlak yang ada disekolah alam Dago, terdiri dari tiga tahapan, yakni: perencanaan, pelaksanaan dan evaluasi, sedangkan untung materi yang berkaitan dengan akhlak yakni: Hidup jadi lebih damai dengan ikhlās, sabār dan pemaaf; Berperilaku amanah dan istiqāmaћ; Berbusana yang baik dan sopan menurut Islām dan Memahami kandungan surah ar-Rūm: 41 tentang kerusakan bumi. Pada kelas dua dan tiga, materi akhlak yang dipelajari siswa, yakni: Akhlak qanā'aћ; Tasamuh; Mengenal sifat takabur, Akhlak bertamu menurut Islām; Memahami kandungan surah Luqman: 18 tentang jangan memalingkan muka dan sombong serta Membaca dan mengartikan hadits tentang kebersihan. Pihak-pihak yang merealisasikannya adalah epala sekolah, wali kelas SL, guru-guru yang mengajar di SL, mereka berupaya memberi teladan yang baik kepada siswa dengan melakukan segala sesuatu sesuai syarīaћ.

Penilaian yang digunakan untuk mengukur keberhasilan pembinaan akhlak siswa adalah penilaian secara tertulis dalam bentuk raport dan juga penilaian secara groovy dalam bentuk kata-kata. 


\section{REFERENSI}

Aat Syafaat, S. S. (2008). Peranan Pendidikan Agama Islam Dalam Mencegah Kenakalan Remaja. Jakarta: Rajawali.

Arifin, Z. (2009). Evaluasi Pembelajaran. Bandung: PT Remaja Rosdakarya.

Balai Pustaka. (2008). Kamus Besar Bahasa Indonesia Pusat Bahasa Edisi Keempat. Jakarta: PT Gramedia Pustaka Utama.

Fattah, N. (2011). Landasan Manajemen Pendidikan. Bandung: PT Remaja Rosdakarya.

Nasution. (1987). Metode Research. Bandung: Jemmars.

Purwanto, M. N. (2012). Administrasi dan Supervisi Pendidikan. Bandung: PT Remaja Rosdakarya. Sa'aduddin, I. A. (2006). Meneladani Akhlak Nabi: Membangun Kepribadian Muslim. Bandung: PT Remaja Rosdakarya.
Siswanto. (2010). Pengantar Manajemen. Jakarta: PT Bumi Aksara.

Sudjana. (2010). Manajemen Program Pendidikan Untuk Pendidikan Nonformal. Bandung: Falah Prodution.

Sugiyono. (2008). Memahami Penelitian Kualitatif. Bandung: Alfabeta.

Sukardi. (2013). Metodologi Penelitian Pendidikan. Jakarta: PT Bumi Aksara.

Susapti, P. (n.d.). Pembelajaran Berbasis Alam. eprints, 1-16.

Tafsir, A. (2011). Ilmu Pendidikan Dalam Perspektif Islam.Bandung: PT Remaja Rosdakarya.

Usman, H. (2010). Manajemen: Teori Praktik \& Riset Pendidikan.Jakarta: PT Bumi Aksara.

Zahruddin, \& Sinaga, H. (2004). Pengantar Studi Akhlak. Jakarta: PT RajaGrafindo Persada. 